Aleksandr L. Shnyparkov ${ }^{1}$, Sven Fuchs ${ }^{2}$, Sergey A. Sokratov ${ }^{3 *}$,

K. Peter Koltermann ${ }^{4}$, Yury G. Seliverstov ${ }^{5}$, Marina A. Vikulina ${ }^{6}$

${ }^{1}$ Head of the Laboratory of snow avalanches and debris flows, Faculty of

Geography, Lomonosov Moscow State University, Moscow, Russia; Leninskie gory 1, 119991, Tel.: +7 495939 3151, e-mail: malyn2006@yandex.ru

${ }^{2}$ Institute of Mountain Risk Engineering, University of Natural Resources and Life Sciences, Vienna, Austria; Peter-Jordan-Strasse 82, A-1190, Tel.: +43 147654 4373, e-mail: sven.fuchs@boku.ac.at

${ }^{3}$ Senior research scientist, Laboratory of snow avalanches and debris flows, Faculty of Geography, Lomonosov Moscow State University, Moscow, Russia; Leninskie gory 1, 119991, Tel.: +7 495939 1861, e-mail: sokratov@geol.msu.ru

* Corresponding author

${ }^{4}$ Head of the Laboratory of Natural Risk Assessment, Faculty of Geography, Lomonosov Moscow State University, Moscow, Russia; Leninskie gory 1, 119991, Tel.: +7 495939 2240, e-mail: koltermann@nral.org

${ }^{5}$ Research scientist, Laboratory of snow avalanches and debris flows, Faculty of Geography, Lomonosov Moscow State University, Moscow, Russia; Leninskie gory 1, 119991, Tel.: +7 495939 2115, e-mail: yus5@yandex.ru

${ }^{6}$ Research scientist, Khibiny educational and scientific base, Faculty of Geography, Lomonosov Moscow State University, Kirovsk, Russia; Zheleznodorozhnaya 10, 184250, Tel.: +7 81531966 15, e-mail: masanna2003@mail.ru

\title{
THEORY AND PRACTICE OF INDIVIDUAL SNOW AVALANCHE RISK ASSESSMENT IN THE RUSSIAN ARCTIC
}

ABSTRACT: In recent years, the Government of the Russian Federation considerably increased attention to the exploitation of the Russian Arctic territories. Simultaneously, the evaluation of snow avalanches danger was enhanced with the aim to decrease fatalities and reduce economic losses. However, it turned out that solely reporting the degree of avalanche danger is not sufficient. Instead, quantitative information on probabilistic parameters of natural hazards, the characteristics of their effects on the environment and possibly resulting losses is increasingly needed. Such information allows for the estimation of risk, including risk related to snow avalanches. Here, snow avalanche risk is quantified for the Khibiny Mountains, one of the most industrialized parts of the Russian Arctic: Major parts of the territory have an acceptable degree of individual snow avalanche risk $\left(<1 \cdot 10^{-6}\right)$. The territories with an admissible $\left(10^{-4}-10^{-6}\right)$ or unacceptable $\left(>1 \cdot 10^{-4}\right)$ degree of individual snow avalanche risk ( 0,5 and $2 \%$ of the total area) correspond to the Southeast of the Khibiny Mountains where settlements and mining industries are situated. Moreover, due to an increase in winter tourism, some traffic infrastructure is located in valleys with an admissible or unacceptable degree of individual snow avalanches risk.

KEY WORDS: Arctic, concept of risk, Khibiny Mountains, snow avalanches

\section{INTRODUCTION}

In the Russian Arctic, where seasonal snow cover is one of the most important components of the environment, the regions endangered by snow avalanches include: the Khibiny Mountains at Kola Peninsula, the Byrranga Mountains, the Putorana Plateau, mountain areas of Yakutia, the Magadan region and Chukotka (Fig. 1). Throughout Russia, the highest degree of 

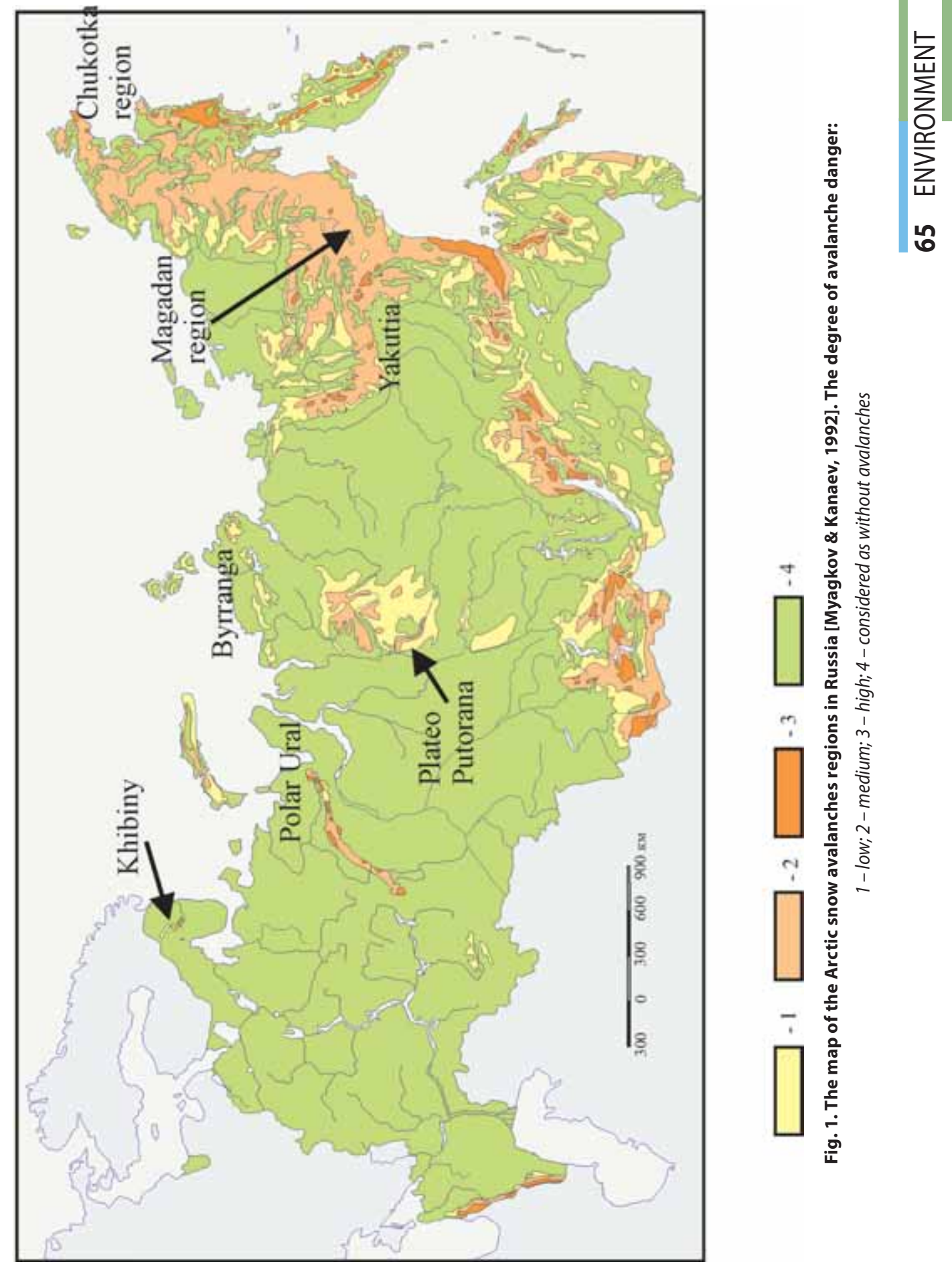
snow avalanche danger is estimated for the Khibiny Mountains and some areas in the Magadan region. At the same time, from an economic point of view these regions are highly developed Arctic territories.

The region of the Khininy Mountains is unique because of the long-term welldocumented dynamics both in industrial development and in natural hazard activity. The development in the Khibiny Mountains started in 1929, when a decision was made to establish an apatite-nepheline mining industry of nationwide importance in this area. The industry appeared in a previously almost unsettled area during a few years. The developers immediately faced the threads of natural hazards, mainly of snow avalanches, they were entirely unprepared during the $1930^{\mathrm{s}}$. After severe losses, the Centre of Avalanche Safety JSC "Apatit" was established, one of the oldest avalanche warning services world-wide.

In 2012, practically all types of infrastructure facilities can be found in the region, including roads and rail roads, pipelines, electric power lines, mining manufactures - both open and pit type, residential buildings, as well as tourism and alpine ski complexes. The industrial complex changes the topography of the territory. While some old mines with the entire corresponding infrastructure are abandoned, new mines in other locations appear. Simultaneously, the development of the tourism industry is remarkable. Due to these changes, the region is a perfect natural "laboratory" for risk assessment and for further development of the conception of risk.

Of course, the processes of snow avalanche formation and the avalanche site distribution also have their unique features in the Khibiny Mountains. Both are determined by the Arctic climate conditions (intensive blizzards, polar night). Moreover, anthropogenic changes of relief including those in the avalanche formation zones are responsible for changes in the conditions of snow accumulation. Numerous natural releases of snow avalanches at the same sites during one winter season, and scheduled artificial snow avalanche releases as a result of Active Avalanche Control are a typical characteristic of this mountain region.

However, without doubts, in-depth analysis of all these unique features within the overall framework of the recently accepted concept of risk can become a base for risk considerations in the Arctic region exploration and development, and would be of considerable importance with respect to further adaptations of the concept of risk for planning development activities in any other territory.

\section{NATURAL CONDITIONS IN THE KHIBINY MOUNTAINS}

The area of the Khibiny Mountains is about $1300 \mathrm{~km}^{2}$ and the cross-section dimension of the massif is approximately $40 \mathrm{~km}$. The Khibiny Mountains represent a tectonic rise of an intrusion of the nepheline syenite - the single massif with flat top, divided by valleys formed among tectonic faults [Myagkov \& Kanaev, 1992]. Numerous denudation craters and erosional cuts complicate the slopes. Quite common are nonsegmented slopes. Cirques and corries* can be found at the highest altitudinal zone.

The absolute altitudes of the Khibiny Mountais are nearly $1200 \mathrm{~m}$ a.s.l. The highest top is Mt. Yudychvmchorr (1200,6 m a.s.l.). The tops are usually flattened or slightly inclined, which is favourable for intensive wind-driven snow transfer and formation of snow cornices and extra snow accumulation on the leeward slopes. The slopes of the valleys are rectilinear or slightly concave with inclination of about $30^{\circ}$. The heights of mountain slopes are 400-700 m.

The winter weather conditions at the Kola Peninsula are determined by alternation of intensive cyclonic activity with periods of anticyclonic weather. The mean annual temperature decreases from $-0,5^{\circ} \mathrm{C}$ in the foothills of the Khibiny Mountains to $-4,9^{\circ} \mathrm{C}$ at

\footnotetext{
* Not synonymic in Russian geomorphological literature.
} 
the tops. Stable temperatures below $0^{\circ} \mathrm{C}$ are found from November to April. The minimal temperatures at all the meteorological station in Khibiny Mountains were registered in January-February. Thawing can happen during winter seasons.

The mean total annual amount of precipitation depends on altitude and is in the range of 1461 to $640 \mathrm{~mm}$. The cold season part of this also depends on altitude. At altitudes above $300 \mathrm{~m}$ it is more than $50 \%$ from annual, while below it is less the $50 \%$. The cold seasons' regime of precipitation is irregular. The maximal cold season monthly precipitations take place in the beginning of a winter (October-November). The monthly precipitation amount decreases in December and January, decreases even more from February till April-May, and then increases up to and including September, which represents the annual maximum in precipitation amount.

The wind regime of the Khibiny Mountains is characterized by intensive cyclonic activity over whole the year. Winds of East (33\%) and North (31\%) directions prevail on the mountain plateaus. Others are the winds of South (27\%) and West (9\%) directions. The long-term mean wind speed changes from 1,6 $\mathrm{m} \mathrm{s}^{-1}$ at "Vostochnaya" to $6 \mathrm{~m} \mathrm{~s}^{-1}$ at "Tsentral'naya" weather stations. The wind regime is characterized by frequent and strong gusts. The gusts are recorded in $20 \%$ of windy days in Kirovsk. The gustiness increases with altitude - it is $35-40 \%$ at the Lovchorr plateau [Zyuzin, 2006]. The wind speed of gusts in the region of Kirovsk was reported up to $48 \mathrm{~m} \mathrm{~s}^{-1}$, it was exceeding $60 \mathrm{~m} \mathrm{~s}^{-1}$ at the Yukspor plateau and was up to $80 \mathrm{~m} \mathrm{~s}^{-1}$ at the Lovchorr plateau [Mokrov, 2000].

The blizzards are directly linked to the wind regime. They are the leading factor in the snow avalanches formation in the Khibiny Mountains. Strong and prolonged blizzards are the characteristic features of the cold season here. The mean annual quantity of days with blizzards is changing from 154 days

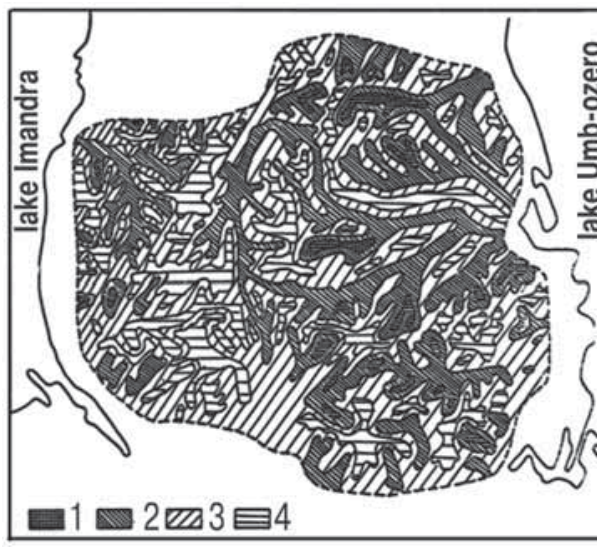

Fig. 2. The map of the distribution of the mean maximal snow depth in the Khibiny Mountains [Kontsevaya et al., 1989] (55 × $\mathbf{4 5} \mathbf{~ k m ~ m a p ) : ~}$

1 - >400 cm; 2 - 200-400 cm; 3 - 100-200 cm; $4-<100 \mathrm{~cm}$

at the flattened tops of mountains with the altitudes up to $1200 \mathrm{~m}$ a.s.l. to 86 days in the bottoms of valleys with the altitudes 200-300 m a.s.l.

The snow cover in the Khibiny Mountains is formed in the conditions of segmented relief under the influence of wind-driven snow transfer and has high spatial and temporal variability (Fig. 2).

Figure 3 shows the dynamics of the maximal snow cover depth at the meteorological station of the Khibiny educationalscientific base of the MSU. The data can be interpreted as representing a slight increase of the winter maximal snow cover depth over time, with high inter-annual variability.

\section{THE CONCEPT OF RISK}

The term "risk" is rather new in ordinary life and environmental scientific literature in Russia. Not long ago, the terms "risk" and "damage" were often considered as equal. For distinction, the "damage" can be interpreted as the weighted consequences of processes and their effects presented in some units, while the "risk" is the probability of such consequences. 


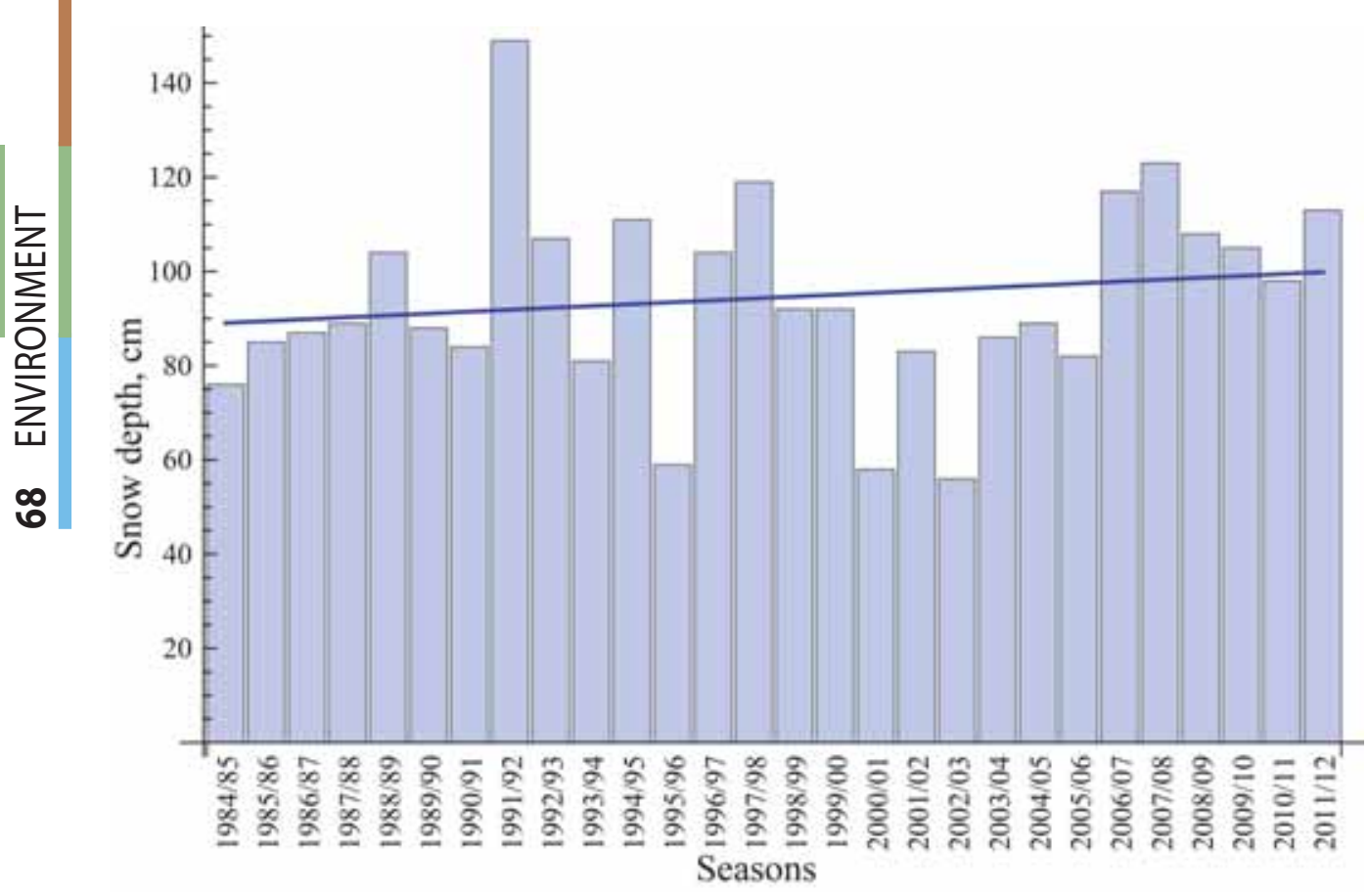

Fig. 3. The winter maximal snow cover depth at the meteorological station of the Khibiny educational-scientific base of the MSU in 1984-2012

Three approaches to the "risk" definition can be allocated: statistical, institutional and social-psychological (behavioural). The most prominent definition of risk in scientific literature is related to statistical characteristics. The following can be noted among them: the probability of danger appearance [Ragozin, 1995; Osipov et. al., 1999]; the potential danger of obtaining undesirable (negative) results [Osipov et. al., 1999]; the repeatability of events with certain intensity [Porfir'ev, 1991; Myagkov, 1995b]; the mathematical expectation of losses, the probability of events - death, illness, accident, catastrophe, probability of event multiplied by its consequences [Bykov \& Murzin, 1997; Myagkov \& Shnyparkov, 2004]; the mathematical expectation in terms of a decrease in life time [Bykov \& Murzin, 1997; Myagkov \& Shnyparkov, 2004], the probability of occurrence of undesirable event [Kovalev et al., 1991], etc.

The institutional approach in the determination of risk may be traced back to Beck [1992]. He characterized the modern society as a "Risk society" and his "risk" definition was interpreted in Russia as a result of certain accepted decisions by a group of persons. This aspect was studied in details by Porfir'ev [1991] during the analysis of management in emergency situations. The similar definition is widely used in jurisdiction [Bratus', 1976; Oigenzikht, 1984].

Socio-psychologists note the specific of relation of a person or group of persons to risk [White, 1976; Al'gin, 1989]. At the end of the $20^{\text {th }}$ century the challenge of ethnocultural differences in the attitude to risk was raised [Myagkov, 1995a; Vashchalova et al., 1997; Myagkov et al., 2003]. These works consider attitude to natural and other risks as determined by inherent perception and ethnic experience.

It is very recent when scientists came to a common definition and understanding of the risk term. The Russian definition of "risk" as accepted by majorities is the probability of an undesirable consequence of a hazard, thus making the "snow avalanche risk" to be 
the probability of undesirable consequences of the effects of snow avalanches on society and industry.

Around the world, risk has been a focal topic of many scientific and professional disciplines as well as practical actors. Consequently, a broad range of conceptualizations of the term exists that show, nevertheless, as lowest common denominator the combination of the likelihood that an undesirable state of reality may occur as a result of natural events or human activities [Kates \& Kasperson, 1983]. Undesirable states of reality are linked to damage, loss, or similar negative and thus adverse effects to those attributes valued by mankind [Seliverstov et al., 2008]. Although the potential for something adverse to occur is appreciated, there is uncertainty when it will realize its potential. This inherently implies that people do make causal connections between the trigger of an event and the consequences. Therefore, this concept is directed towards the future state of the studied system [Renn, 2008b].

Technically, these processes and situations that have the potential to bring about undesirable states of reality are referred to as a hazard, while two different meanings thereby exist: (1) the physical process or activity that is potentially damaging; and (2) the threatening state or condition, indicated by likelihood of occurrence and described by a likelihood or probability of occurrence of a given magnitude in a specified location and a specified period of time [Myagkov, 1995b; Fuchs, 2009]. Following the latter and thus funnelling down the latent danger of a specifically defined hazard setting, results in the concept of risk, once the adverse effects can clearly be linked to these settings and quantified by numbers. The definition of risk, therefore, contains three elements: (1) outcomes that have an impact upon what humans value; (2) the likelihood of occurrence; and (3) a specific context in which the risk may materialize [Renn, 2008b]. Thus, risk is the potential loss to the exposed system, resulting from the convolution of hazard and consequences at a certain site and during a certain period of time. In the perspective of natural sciences, this relationship is regularly expressed by the risk equation (Equation 1), which with respect to natural hazards is conceptualized by a quantifying function of the probability of occurrence of a hazard scenario $\left(p_{s i}\right)$ and the related consequences on objects exposed $\left(c_{O_{j}}\right)$ :

$R_{i, j}=f\left(p_{s i} c_{0 j}\right)$.

The consequences can be further quantified by the elements at risk and their extent of damage [e.g., Fuchs, 2009], and specified by the individual value of objects $j$ at risk $\left(A_{0}\right)$, the related vulnerability in dependence on scenario $i\left(v_{O j}, s_{i}\right)$, and the probability of exposure $\left(p_{O j, s_{i}}\right)$ of objects $j$ to scenario $i$ (Equation 2).

$R_{i, j}=f\left(p_{S i,} A_{O j,} V_{O j,}, s_{i j} p_{O j, ~ S i}\right)$.

This quantitative definition of risk provides the framework for probabilistic risk assessment and has its roots in both technical risk analyses [e.g., Schneider, 1991] and actuarial analyses [e.g., Schwarz, 1996; Freeman \& Kunreuther, 2003].

Nevertheless, this technical concept of risk analysis has attracted certain criticism from the social sciences' side [Freudenburg, 1988; Adams, 1995] due to the following reasons, cf. Renn [2008a]:

- What people perceive as an undesirable effect is related to their values and preferences, which is not mirrored by the technical risk equation accordingly;

- The interactions between human activities and consequences are more complex than average probabilities used in technical risk analyses are able to capture [Fischhoff et al., 1982; Zinn \& Taylor-Gooby, 2006];

- Theinstitutional structure of managing and controlling risks is prone to organizational failures and deficits that may increase the actual risk [Short, 1984]; 
- Risk analyses cannot be regarded as an objective, value-free scientific activity [Fischhoff, 1995] and values are reflected in how risks are characterized, measured, and interpreted;

- The numerical combination of magnitude, frequency and consequences assumes equal weight for the hazard component and the elements at risk exposed. Consequently, no difference between high-consequence/ low-probability and low-consequence/ high-probability events is made, whereas people show distinct preferences for one or the other [Slovic, 1987];

- Technical risk analyses can provide only aggregate data over larger segments of the population and long-time duration. Each individual, however, may face different degrees of risk depending upon the variance of the probability distribution [Cullen \& Small, 2004]. Moreover, cognitive psychologists and decision researchers investigated the underlying patterns of individual perception of risk and identified a series of heuristics and biases that govern risk perceptions [Vlek \& Stallen, 1981; Slovic, 1987]. Studies on risk perception, instead, have clearly revealed that most individuals have a much more comprehensive conception of risk including aspects of voluntariness, personal ability to influence the risk, familiarity with the hazard and so on [Slovic et al., 1982; Slovic, 1987].

These findings from social sciences stimulated equivalent results within the geographic hazard community. It has been repeatedly argued that any natural hazard and resulting risk, and consequently any form of natural disaster is caused by humans and not by nature [e.g., Wisner et al., 2004] since any process operating in nature is only based on physical laws. Any damage due to natural hazards is thus the result of bad or false adaptation to nature, such as misdirected land use, improper development planning, inappropriate building techniques and materials, as well as missing preparedness and insufficient awareness of the people concerned [Dombrowsky, 2002], these arguments are also used by natural scientists with respect to the so-called passive mitigation of natural hazard risk [e.g., Holub \& Fuchs, 2009]. Obviously, the concept of risk is rooted in the interaction between society and the physical environment, which is a fundamental starting point of any (and therefore also geographic) research on natural hazard risk. Most scientists point to Starr's [1969] seminal article on social benefit versus technological risk as the beginning of quantitative risk analysis and the development of the risk paradigm [Cutter, 2001].

Nevertheless, from a natural sciences point of view, dealing with undesired outcomes of natural events, above all triggered by gravitational dynamics, is rooted in hazard assessment [Schuster, 1978]. These approaches had been further developed towards the concept of risk, while in recent years, the assessment of vulnerability emerged as a concept increasingly in the focus of research [Fuchs et al., 2007]. This shift from hazard to risk and vulnerability analyses and evaluation is, from a technical point of view, mirrored in the risk equation, where all parameters needed are combined as a functional relationship (Equation 2).

With respect to mountain hazards, major contributions to the historical development of natural hazard risk management are given in Fell et al. [2008] focusing on landslide risk issues in a broader sense and taking an international viewpoint. Complementary to this, in al pine countries, namely in Switzerland, essential inputs originate from the Berne school [Kienholz, 1994]. These approaches were further refined by Bollinger et al. [2000] and Keiler et al. [2004] with respect to smallscale (regional) analyses; and more recently by Fuchs et al. [2008] and others focusing on large-scale (local) analyses of individual process areas. The overall concept of risk, as currently in use in alpine countries to manage natural hazard risk, is based on general ideas outlined in Kienholz et al. [2004] and Fuchs [2009]. 


\section{RISK ANALYSIS}

The main objective of hazard analysis is to identify and characterize potential processes together with an evaluation of their corresponding frequency of occurrence and magnitude [Vilchek et al., 2005; Fuchs et al., 2008]. Thereby, qualitative models include the analysis of event documentation and other sources, while quantitative methods include the statistical analysis of process parameters, probabilistic prediction analyses, and process-based numerical analyses.

The qualitative identification of hazard processes requires an understanding of triggering mechanisms in relationship to the process characteristics, i.e. the relationship between geomorphology, hydrogeology, geology, failuremechanics, climateconditions and vegetation cover [e.g., Shnyparkov, 2004; Fell et al., 2008]. Methods, which may be used to identify hazards include geomorphological mapping, gathering of historic information on processes in similar locations, topography, geology and climate [e.g. from maintenance records, aerial photographs, newspapers, chronicles, etc., see Kienholz \& Krummenacher, 1995; Seliverstov et al., 2008]. Such heuristic approaches, based on a priori knowledge, local experience as well as expert judgment, often provide the only information available [Fuchs et al., 2001] and are therefore increasingly included in hazard analysis procedures [Mazzorana \& Fuchs, 2010]. Keiler et al. [2004] present a method of how to convert analogue hazard information into a GIS environment. As a result, the types of potential processes under consideration will be classifiable. Additionally, the physical extent of each process will be identified, including location, spatial extent and possible volumes available for displacement.

The quantitative process characterization includes: (1) the determination of the occurrence probability of the studied processes, i.e. the recurrence interval and as such the frequency of the event; and (2) the quantitative estimation of principal process parameters needed for hazard assessment, i.e. the process magnitude, runout length, and deposition area [Fuchs et al., 2008]. In order to describe the frequency of an event, several probability concepts may be used. However, with respect to mountain hazards, the probability of the event itself is often not quantifiable due to a lack of measurement data resulting from the complexity between cause and effect [Fuchs \& McAlpin, 2005; Vilchek et al., 2005]. Consequently, the probability of the main triggering mechanism (e.g., recurrence interval of meteorological phenomena) or the probability to reach a defined point during run-out in the deposition area will be used as a proxy instead, which results in considerable uncertainties of the hazard assessment [Mazzorana \& Fuchs, 2010]. Therefore it is necessary to explicitly define the probability value to be used in a set of calculations. Despite considerable efforts to propose the likelihood of process occurrence in a particular catchment, there are no rigorous methods that allow a strict assessment for the determination of an exact probability of occurrence so far, neither based on physical characteristics of a catchment nor statistical analyses [Fuchs et al., 2008]. The (heuristically gathered) information available on past process magnitudes is often the most reliable indication. Quantitative methods to characterize processes can be divided into two different approaches [Fuchs et al., 2008]: (1) statistical and probabilistic prediction analysis; and (2) process-based and numerical analysis. In contrast to qualitative methods, quantitative approaches draw comparisons and/or classifications of different process events in a more comprehensible style. Thus, quantitative methods are widely applied for hazard analyses on a federal and regional scales [Fuchs et al., 2004; Shnyparkov, 2004].

\section{RISK ASSESSMENT}

Integrated investigations, aimed at developing methodologies and techniques of risk assessment and possible damage evaluation connected with various dangerous natural processes and phenomena, are 
being conducted in the Research Laboratory of Snow Avalanches and Debris Flows for a long time. More recently they become also part of the research activity of the Natural Risk Assessment Laboratory (Faculty of Geography, M.V. Lomonosov Moscow State University). These methodologies and techniques can be used in different scales and allow to get necessary estimations for local population, migrating people and tourists, as well as for many categories of protected systems - roads, railways, means of transportation, etc. To encourage a consistent methodology of general use, irrespective of the hazard or risk, in this paper a method of individual avalanche risk assessment for large mountain regions, as an example of wider use, is presented. It was elaborated on the basis of the methodology suggested and already tested for karst risk evaluation by Yolkin [2004].

Avalanche risk includes the probability of various losses caused by snow avalanche impact over a definite period of time in the certain area [Myagkov, 1995b]. These losses can be expressed by use of different indices:

- Annual number of fatalities;

- Probability of decease of an individual from the particular group of people living within the given area permanently or staying there temporarily;

- Probable damage magnitude;

- Probable proportion of destroyed and damaged buildings and other constructions;

- Probable costs of forced stoppage emerged in transportation systems as a result of avalanche activity.

Possible damage evaluation takes into account various social and economic parameters, as well as a number of avalanche activity characteristics, which determine the probability of losses [Molotkov, 1992; Seliverstov, 1992]. Thematic maps compiled by researchers of the MSU Faculty of Geography [Kotlyakov, 1997] were used as the principal source of snow and avalanche information. Calculations were made with the help of GIS Maplnfo. All areas under investigation were divided into exact squares (grid cells), each side of which equalled $3 \mathrm{~km}$ on the map applied as a basis for estimation.

To get the values of avalanche risk indices for all grid cells subsequent calculations of the following parameters were made:

Population vulnerability in time $\left(v_{t}\right)$ : This index defines the duration of stay (time of exposure) of an individual in avalanche hazard areas during the average day and year. It is estimated as a function of the duration of stay of an individual and his possible location within the dangerous territory:

$$
V_{t}=\frac{t_{d}}{24} \times \frac{t_{y}}{365}
$$

where $t_{d}$ is the average duration of stay of a typical local individual within the dangerous territory during one day, $t_{y}$ is the average duration of stay of a typical local individual within the dangerous territory during one year. The values of $t_{d}$ were estimated on the basis of expert evaluation and generalization mainly due to the presence or absence of human settlements and roads in areas under investigation. In this project the following values are applied:

- If there are no roads and human settlements, $t_{d}$ is equal to $1 \mathrm{sec}$;

- If there are some roads, $t_{d}$ is equal to 1 min;

- If there are any human settlements, $t_{d}$ is equal to 1 hour.

The values of $t_{y}$ correspond to the annual duration of avalanche danger period (the number of days).

Population vulnerability in space $\left(V_{s}\right)$ : This is a function of a degree in which 
a territory is exposed to the impact of snow avalanches:

$$
V_{s}=\frac{S_{y}}{S_{t}},
$$

where $S_{y}$ is the area of a hazard zone (exposed to the impact of natural disaster) within the territory under investigation, $S_{t}$ is the total area of the given territory. Small-scale estimation of this index presents a rather difficult task. That is why the corresponding figures were calculated on the basis of a close correlation, existing between the susceptibility of a territory to snow avalanches and such parameters as absolute height, relative height and landscape type, proved by Blagoveshchenskii [1991]. To determine particular values of the index both hypsometric and landscape maps of different territories under investigation were used.

Complete social (collective) avalanche risk $\left(R_{\text {col }}\right)$ of fatal accidents among people is a function of the population vulnerability in time and space, avalanche frequency and population density:

$R_{\text {col }}=F \times d \times V_{t} \times V_{s}$

where $F$ is the recurrence interval of avalanches, $d$ is the density of population in the area under investigation. This index shows the annual number of fatalities as the result of an avalanche impact.

Individual avalancherisk $\left(R_{\text {ind }}\right)$ is the probability of fatal accident led to the death of an individual from some group of people within the territory under investigation for the period of one year. This index is calculated by dividing the complete social risk on the total population of the given area $(p)$ :

$R_{\text {ind }}=\frac{R_{f}}{p}$.

Following the recommendations of the Russian Ministry of Emergency Situations [Vorob'ev, 2005], three types of zones with different levels of individual avalanche risk are distinguished on avalanche risk maps. Values less than $1 \cdot 10^{-6}$ indicate acceptable risk areas, where no special avalanche protection measures for the population are needed and new buildings and other constructions can be erected without restriction. Values from $1 \cdot 10^{-6}$ to $1 \cdot 10^{-4}$ define the boundaries of admissible risk areas, where considerable avalanche protection measures for the population must be carried out and the erection of buildings and other constructions is possible only in combination with largescale avalanche control programs, which may lower individual avalanche risk indices to the acceptable level. Values more than $1 \cdot 10^{-4}$ characterize unacceptable risk areas, where no new construction projects are permitted and for existing systems and developed lands a whole set of avalanche control measures is necessary and compulsory to protect the population and to lower the level of risk.

\section{AVALANCHE ACTIVITY AND RISK IN THE KHIBINY MOUNTAINS}

In average, the duration of an avalancheendangered period in the Khibiny Mountains is 240 days. The mortis causa were reported immediately after the first snowfalls. Normally, the releases of snow avalanches are noted in October and continue up to May. In some years the first snow avalanches releases were observed even in September, while the last were observed in June. Most of snow avalanches releases (slightly more than 50\%) happen in the period from February to April.

Practically all the types of snow avalanches (classification by "cause of formation" [Akkuratov, 1972]* $^{*}$ ) can take place in the Khibiny Mountains. The majority is presented by the avalanches caused by blizzards (about $80 \%$ of the total number of snow avalanches). During the avalanche-endangered period, in average, there are 44 days when actual snow avalanches are observed. From year to year this number varies from 22 to 71 days. The repeatability of snow avalanche releases is

* The one, most widely used over several dozen years in USSR and Russia with awareness on existence of other classifications, including the International one. 


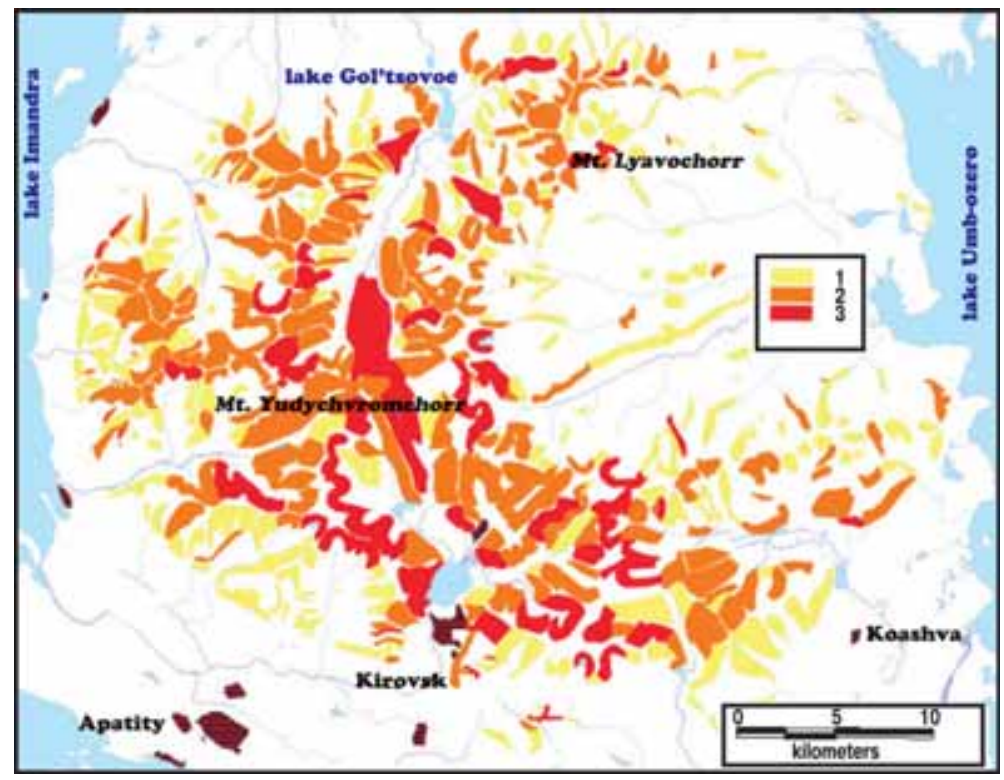

Fig. 4. The degree of snow avalanche activity:

1 -low; 2 - medium; 3 - high

high. In average, 107 avalanches are released from 50 avalanche catchments observed by the Centre of Avalanche Safety JSC "Apatit", i.e. more than 2 avalanches per year. There can be more than 10 avalanches per season from some avalanche catchments. The volumes of snow avalanches in the Khibiny Mountains also vary in a wide range: from

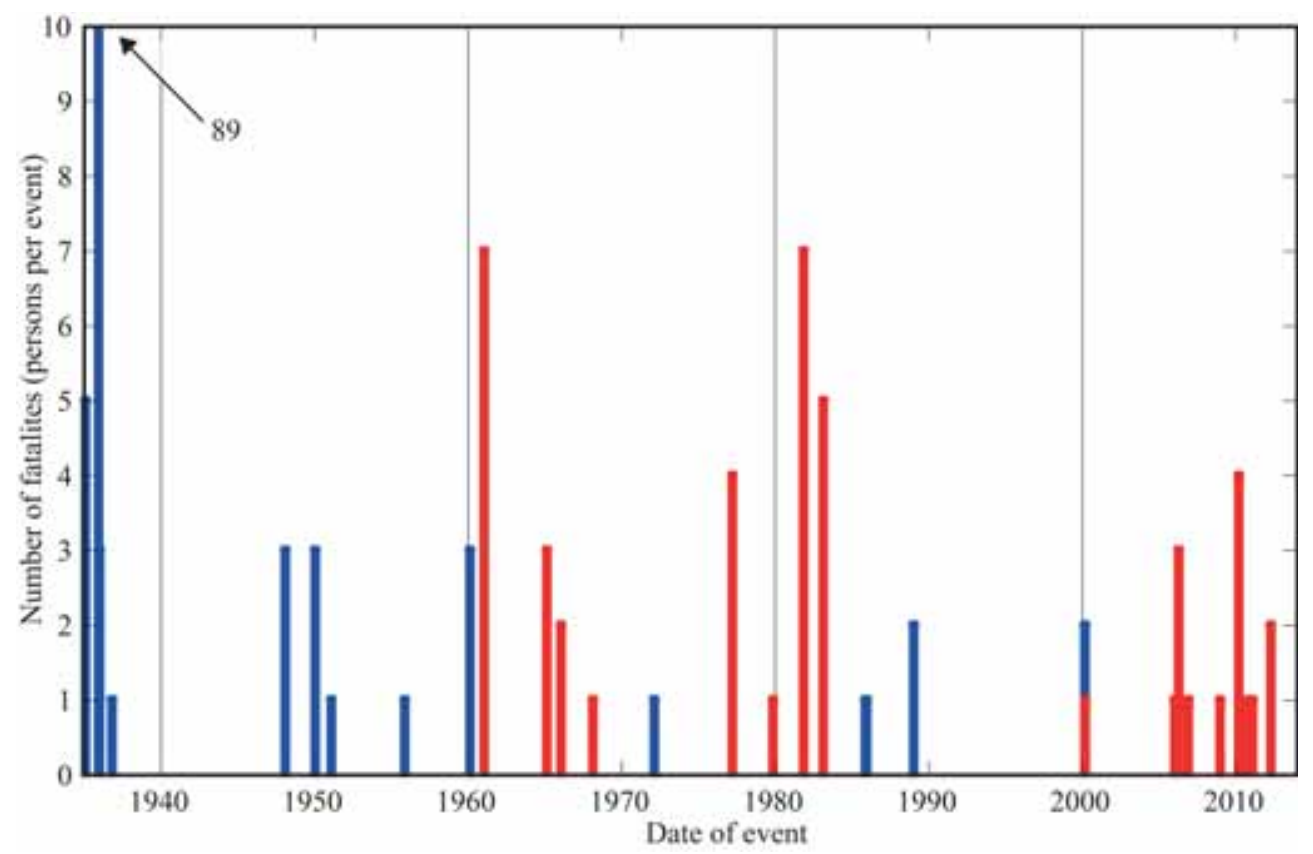

Fig. 5. The quantity of fatalities caused by snow avalanches in the Khibiny Mountains during the period of registering by the Centre of Avalanche Safety JSC "Apatit" (1935-recent): 
a few thousands up to hundreds thousands $\mathrm{m}^{3}$. The maximal volume during the period of instrumental observations was reported as 1125 thousand $\mathrm{m}^{3}$.

According to the classification, constructed on the base of quantity of avalanche paths per $\mathrm{km}$ of thalweg against the repeatability of avalanches per season [Vikulina, 2009], most of the region of the Khibiny Mountains corresponds to a high and medium degree of snow avalanche activity (Fig. 4).

The total amount of registered fatalities from the $1930^{5}$ to 2012 by the Centre of Avalanche Safety JSC "Apatit" caused by snow avalanches in the Khibiny Mountains is 164. Their dynamics are presented in Figure 5. Taking the long-term mean quantity of people in the region as 34 000, the average implemented individual snow avalanche risk for whole the area is $6,3 \cdot 10^{-5}$. This put the degree of individual snow avalanche risk to the middle of the scale [Vorob'ev, 2005] between acceptable and unacceptable. Thus, any considerable changes in population or avalanche activity can move the total degree of risk in any direction. At higher resolution the variability is high (Fig. 6). Figure 6 also shows the on-going change in the category of the majority of the snow avalanches victims - from the locals to the visiting tourists.

Figure 6 shows the results of the individual snow avalanches risk estimation for the Khibiny Mountains by the method described above.

\section{CONCLUSIONS}

The presented assessment of risk in the Khibiny Mountains allowed to conclude that the most of the analysed territory corresponds to acceptable $\left(<1 \cdot 10^{-6}\right)$, according to the recommendations of the Russian Ministry of Emergency Situations [Vorob'ev, 2005], degree of individual snow avalanches risk (Fig. 6). The areas with admissible $\left(10^{-4}-10^{-6}\right)$ and unacceptable $\left(>1 \cdot 10^{-4}\right)$ degrees of individual snow avalanche risk (0,5 and 2\% of the total territory respectively) are situated at the Southeast of the mountain massif, where most of industry and settlements are situated. Additionally, the territories with admissible and unacceptable degree of individual snow avalanche risk are situated in the valleys of the rivers Kukisvumchorr and

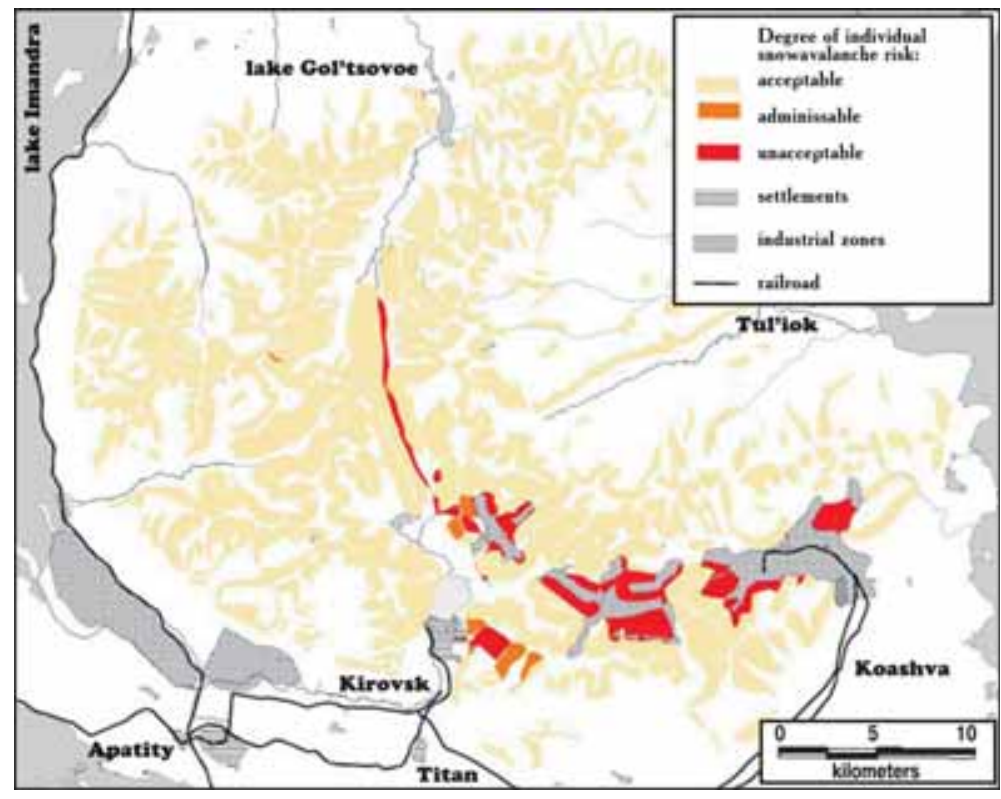

Fig. 6. The individual snow avalanche risk in the Khibiny Mountains 
Kuniiok, where most popular winter touristic routes are. Thus, the main threat from snow avalanches is to mining industry, motor and railroads, ski resorts and winter tourists. The territories with the highest avalanche activity (Fig. 4) are not the same as the territories with the highest individual snow avalanches risk (Fig. 6).

The further development of the territory will, without doubts, change the pattern presented by Figure 6. However, at present time the $100 \%$ justification of the snow avalanche forecast is impossible. It also applies to complete termination of the people access to the avalanches-endangered slopes during the avalanche-endangered time periods, which does not allow expectation of 100\% success in Active Avalanche Control. Due to high cost, the $100 \%$ protection of people by technical mitigation measures can hardly be expected. Thus, the spatial and temporal vulnerability of people to snow avalanches in the Khibiny Mountains cannot be eliminated. It can be decreased by effective avalanche-protective measures and by education of local people and visitors.

The long-term experience from the Khibiny Mountains should be accounted for in the planning of the future development of other regions in the Russian Arctic. Not only new industrial facilities should not become victims of disastrous mistakes in positioning of building in dangerous sites (the 89 fatalities at December 51935 at Figure 5), but simplification of the access to a site inevitably brings visitors to a developing area, which are not always prepared to natural conditions in there, and which the area is not completely prepared to receive in safety.

\section{ACKNOWLEDGEMENT}

The research leading to these results has received partial funding from the European Community's Seventh Framework Programme under grant agreement No 262693.

\section{REFERENCES}

1. Adams, J. (1995). Risk. London: Routledge. 228 p.

2. Akkuratov, V.N. (1972). Snow avalanches in the Khibiny Mountains. Cand. Sci. thesis. Kirovsk: Moscow State University. 124 p. (in Russian).

3. Al'gin, A.P. (1989). Risk and its role in social life. Moscow: Mysl'. 192 p.

4. Beck, U. (1992) From industrial society to the risk society: Questions of survival, social structure and ecological enlightenment. Theory, Culture \& Society, 9 (1), p. 97-123.

5. Blagoveshchensky, V.P. (1991). Determination of avalanche loads. Alma-Ata: Gylym. 116 p.

6. Bollinger, D., Buri, H., della Valle, G., Hegg, C., Keusen, H.R., Kienholz, H., Krummenacher, B., Mani, P., Roth, H. (2000). Gefahrenhinweiskarte des Kantons Bern 1:25000. Internationales Symposion Interpraevent, Villach.

7. Bratus', S.N. (1976). Legal liability and legality: outline of theory. Moscow: Yuridicheskaya literatura. $214 \mathrm{p}$.

8. Bykov, A.A., Murzin, N.V. (1997). Problems in analysis of the safety of humans, society and Nature. Sankt-Petersburg: Nauka. 247 p.

9. Cullen, A., Small, M. (2004). Uncertain risk: The role and limits of quantitative assessment. Risk analysis and society: An interdisciplinary characterization of the field. T. McDaniels, M. Small, Eds. Cambridge: Cambridge University Press, p. 163-214.

10. Cutter, S. (2001). The changing nature of risks and hazards. American hazardscapes. S. Cutter, Ed. Washington: Joseph Henry Press, p. 1-12. 
11. Dombrowsky, W. (2002) Flußhochwasser - ein Störfall der Vernunft? Gaia, 11 (4), p. 310-311.

12. Fell, R., Corominas, J., Bonnard, C., Cascini, L., Leroi, E., Savage, W. (2008) Guidelines for landslide susceptibility, hazard and risk zoning for land-use planning. Engineering Geology, 102 (3-4), p. 85-98.

13. Fischhoff, B., Slovic, P., Lichtenstein, S. (1982) Lay foibles and expert fables in judgments about risk. The American Statistician, 36 (3, Part 2), pp. 240-255.

14. Fischhoff, B. (1995) Risk perception and communication unplugged: Twenty years of process. Risk Analysis, 15 (2), p. 137-145.

15. Freeman, P., Kunreuther, H. (2003). Managing environmental risk through insurance. International Yearbook of Environmental and Resource Economics 2003/04. H. Folmer, T. Tietenberg, Eds. Cheltenham: Edward Elgar, p. 159-189.

16. Freudenburg, W. (1988) Perceived risk, real risk: Social science and the art of probabilistic risk assessment. Science, 242 (4875), p. 44-49.

17. Fuchs, S., Keiler, M., Zischg, A. (2001). Risikoanalyse Oberes Suldental (Vinschgau). Konzepte und Methoden für die Erstellung eines Gefahrenhinweis-Informationssystems (Innsbrucker Geographische Studien, 31). Innsbruck: Universität Innsbruck. 182 p.

18. Fuchs, S., Bründl, M., Stötter, H. (2004). Development of avalanche risk between 1950 and 2000 in the municipality of Davos, Switzerland. Natural Hazards and Earth System Sciences, 4 (2), p. 263-275.

19. Fuchs, S., McAlpin, M. C. (2005) The net benefit of public expenditures on avalanche defence structures in the municipality of Davos, Switzerland. Natural Hazards and Earth System Sciences, 5 (3), p. 319-330.

20. Fuchs, S., Heiss, K., Hübl, J. (2007) Towards an empirical vulnerability function for use in debris flow risk assessment. Natural Hazards and Earth System Sciences, 7 (5), p. 495-506.

21. Fuchs, S., Kaitna, R., Scheidl, C., Hübl, J. (2008) The application of the risk concept to debris flow hazards. Geomechanics and Tunnelling, 1 (2), p. 120-129.

22. Fuchs, S. (2009) Susceptibility versus resilience to mountain hazards in Austria - Paradigms of vulnerability revisited. Natural Hazards and Earth System Sciences, 9 (2), p. 337-352.

23. Holub, M., Fuchs, S. (2009) Mitigating mountain hazards in Austria - Legislation, risk transfer, and awareness building. Natural Hazards and Earth System Sciences, 9 (2), p. 523-537.

24. Kates, R., Kasperson, J. (1983) Comparative risk analysis of technological hazards (a review). Proceedings National Academy of Science USA, 80 (22), p. 7027-7038.

25. Keiler, M., Fuchs, S., Zischg, A., Stötter, J. (2004). The adaptation of technical risk analysis on natural hazards on a regional scale. Geomorphologische und hydrologische Naturgefahren in Mitteleuropa (Zeitschrift für Geomorphologie, Supplementbände, 135). M. Becht, B. Damm, Eds. Berlin, Stuttgart: Gebrüder Borntraeger, p. 95-110.

26. Kienholz, H. (1994) Naturgefahren - Naturrisiken im Gebirge. Schweizerische Zeitschrift für Forstwesen, 145 (1), p. 1-25.

27. Kienholz, H., Krummenacher, B. (1995). Symbolbaukasten zur Kartierung der Phänomene (Mitteilungen des Bundesamtes für Wasserwirtschaft, 6). Bern: Bundesamt für Wasserwirtschaft, Bundesamt für Umwelt, Wald und Landschaft. 60 p.

28. Kienholz, H., Krummenacher, B., Kipfer, A., Perret, S. (2004) Aspects of integral risk management in practice - Considerations with respect to mountain hazards in Switzerland. Österreichische Wasser- und Abfallwirtschaft, 56 (3-4), p. 43-50. 
29. Kontsevaya, V.V., Sokolov, V.M., Freidlin, V.S. (1989). Study of the snow accumulation at various relief forms in the Khibiny Mountains. Proceedings of the 3-rd all-Union conference on avalanches. Leningrad: Gidrometeoizdat, p. 232-240.

30. Kotlyakov, V.M., Ed. (1997). World atlas of snow and ice resources. Moscow: IG RAN, NPP "Kartografiya", $392+263+270$ p.

31. Kovalev, E.E., Ivanov, V.I., Pakhomov, B.Y., Ivanova, A.A. (1991) New techniques and problems of the human safety. Problems of Philosophy, (5), p. 49-59.

32. Mazzorana, B., Fuchs, S. (2010) Fuzzy Formative Scenario Analysis for woody material transport related risks in mountain torrents. Environmental Modelling \& Software, 25 (10), p. 1208-1224.

33. Mokrov, E.G. (2000) Climatic specifics of the Khibiny Mountais as a factor affecting the effecivity of technological solutions. Mining Journal, (3), p. 17-19 (in Russian).

34. Molotkov, N.M. (1992). Risk of natural hazards in mountaineering. Survey mapping of Natural dangers and Natural hazards. Moscow: Moscow State University, p. 221-232.

35. Myagkov, S.M., Kanaev, L.A., Eds. (1992). Geography of avalanches. Moscow: MSU, 332 p.

36. Myagkov, S.M. (1995a) [Problem of the ethno-cultural differences in the attitude to risk. Problems of safety in emergency situations, (12), pp. 23-32.

37. Myagkov, S.M. (1995b). Geography of Natural risk. Moscow: Moscow State University. 224 p.

38. Myagkov, S.M., Porfir'ev, B.N., Lesnykh, V.V., Shnyparkov, A.L. (2003). Perception of Natural risks and front-end relationships. Natural disasters in Russia. Assessment and management of Natural risks. Moscow: Kruk, p. 258-263.

39. Myagkov, S.M., Shnyparkov, A.L. (2004). The concept of risk. Natural-Anthropogenic Processes and Environmental Risk. (Geography, society and environment, N.S. Kasimov, Ed. Moscow: Gorodets, p. 265-274.

40. Oigenzikht, V.A. (1984) Will and risk. Jurisprudence, (4), p. 41-46.

41. Osipov, V.I. et. al., Eds. (1999). Security of Russia. Legal, social-economoc and scientifictechnological aspects. Regional problems of security with risk of occurrence of Natural and technogenic catastrophes accounted for. Moscow: Znanie, 672 p.

42. Porfir'ev, B.N. (1991). The problems of safety at emergency situations. Management in emergency situations: the problems of theory and practice. The outcome of science and technology, Moscow: VINITI. 204 p.

43. Ragozin, A.L. (1995). Recent state and perspectives of the estimation and of administration of the Natural risks in construction. Analysis and estimation of the Natural and technogenic risk in construction. Moscow: PNIIIS, pp. 9-25.

44. Renn, O. (2008a) Concepts of risk: An interdisciplinary review - part 2: Integrative approaches. Gaia, 17 (2), p. 196-204.

45. Renn, O. (2008b) Concepts of risk: An interdisciplinary review - part 1: Disciplinary risk concepts. Gaia, 17 (1), p. 50-66.

46. Schneider, J., Ed. (1991). Risiko und Sicherheit technischer Systeme. Auf der Suche nach neuen Ansätzen. (Monte Verità: proceedings of the Centro Stefano Franscini. Basel: Birkhäuser, 289 p.

47. Schuster, R., Ed. (1978). Landslides. Analysis and control. Washington: National Academy Press, $234 \mathrm{p}$. 
48. Schwarz, R. (1996). Ökonomische Ansätze zur Risikoproblematik. Risikoforschung zwischen Disziplinarität und Interdisziplinarität. G. Banse, Ed. Berlin: Edition Sigma, p. 125-131.

49. Seliverstov, Y., Glazovskaya, T., Shnyparkov, A., Vilchek, Y., Sergeeva, K., Martynov, A. (2008) Assessment and mapping of snow avalanche risk in Russia. Annals of Glaciology, 49, p. 205-209.

50. Seliverstov, Y.G. (1992). The methodology of calculation of the economic loss due to avalanches obstructions at the motorroads (with Kirgizia as an example). Survey mapping of Natural dangers and Natural hazards. Moscow: Moscow State University, pp. 233-242.

51. Shnyparkov, A., Ed. (2004). Snow avalanches, debris flows and risk assessment. Moscow: Geograficheskii fakul'tet MGU, 203 p.

52. Short, J.F. Jr. (1984) The social fabric at risk: Toward the social transformation of risk analysis. American Sociological Review, 49 (6), p. 711-725.

53. Slovic, P., Fischhoff, B., Lichtenstein, S. (1982) Why study risk perception? Risk Analysis, 2 (2), p. 83-93.

54. Slovic, P. (1987) Perception of risk. Science, 236 (4799), p. 280-285.

55. Starr, C. (1969) Social benefit versus technological risk. Science, 165 (3899), p. 1232-1238.

56. Vashchalova, T.V., Myagkov, S.M., Shnyparkov, A.L. (1997). The problem of people attitude to Natural and other risk. Abstracts of the presentations at the International conference "Analysis and estimation of the Natural risks in construction". Moscow, pp. 143.

57. Vikulina, M.A. (2009). Assessment of snow avalanche activity, hazard and risk (with Khibiny Mountains as an example). Cand. Sci. thesis.: Moscow State University. 230 p. (in Russian).

58. Vilchek, Y., Glazovskaya, T., Seliverstov, Y. (2005) Some approaches to estimation of avalanche danger and avalanche risk. Materials of Glaciological Studies, (99), p. 123-128.

59. Vlek, C., Stallen, P.-J. (1981) Judging risks and benefits in the small and the large. Organizational Behavior and Human Performance, 28 (2), p. 235-271.

60. Vorob'ev, Y.L. (2005). Personal and social safety (some aspects of State policy). EMERCOM; Moscow: Delovoi ekspress. 376 p.

61. White, G.F., Ed. (1976). Natural Hazards: Local, National, Global. New York: Oxford University Press Inc, $304 \mathrm{p}$.

62. Wisner, B., Blaikie, P., Cannon, T., Davis, I. (2004). At risk. Natural hazards, people's vulnerability and disasters. London: Routledge. $471 \mathrm{p}$.

63. Yolkin, V.A. (2004). Regional assessment of karst hazard and risk (with Republic of Tatarstan as an example). Cand. Sci. thesis. Moscow: Institute of Geoecology RAS. 158 p.

64. Zinn, J., Taylor-Gooby, P. (2006). Risk as an interdisciplinary research area. Risk in social science. P. Taylor-Gooby, J. Zinn, Eds. Oxford: Oxford University Press, p. 20-53.

65. Zyuzin, Y.L. (2006). Severe face of Khibiny. Murmansk: Reklam. poligrafiya. 234 p. 


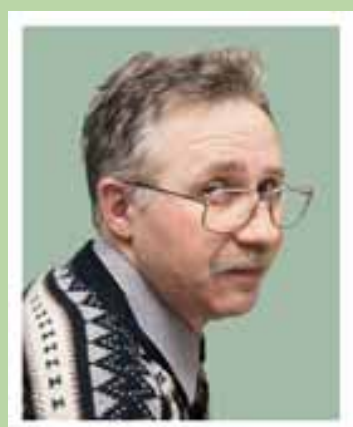

Alexandr L. Shnyparkov studied glaciology at the Faculty of Geography, Lomonosov Moscow State University and graduated in 1980. Since 1980 he is working in the Research Laboratory of Snow Avalanches and Debris Flows, Faculty of Geography, Lomonosov Moscow State University, recently as the Head of the Laboratory. He received his Ph. D. degree in 1991. His research focuses on Natural hazards, danger and risk assessment. Main publications: The analysis of the distribution of emergency situations of Natural origin at the end of XX - beginning of XXI century at the territory of Russia (2011, with co-authors); Debris flows risk in Russia (2009, with co-authors); Natural risk for the cities of Russia (2007, with co-authors).

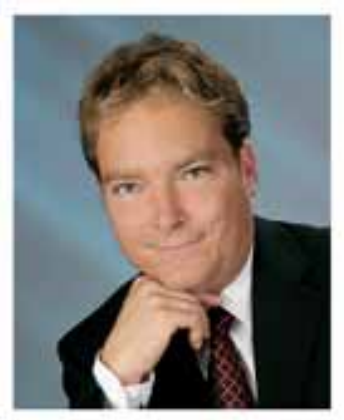

Sven Fuchs studied Geography and Geology at the Universities of Munich (Germany) and Innsbruck (Austria) and graduated in 2000 (MSC). He holds a PhD obtained in 2004 for his spatiotemporal studies on snow avalanche risk undertaken during a four years appointment at the Swiss Federal Institute for Snow and Avalanche Research SLF in Davos, Switzerland; and a Habilitation (venia docendi for Geography, 2010) for his works related to human-environment interaction in mountain regions. Currently he is Assistant Professor at the University of Natural Resources and Life Sciences in Vienna, Austria. His research includes risk assessment and risk management for mountain hazards, vulnerability analyses, human-environment interaction, and geomorphology. He has extensive research experiences in mountain regions of Europe, Southeast Asia, Central Africa, and the Russian Federation. The list of publications can be accessed by following this link: www.sven-fuchs.de/links/publikat.html.

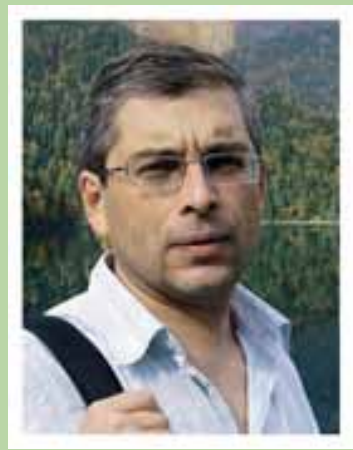

Sergey A. Sokratov studied glaciology and geocryology at the Faculty of Geography, Moscow State University, and graduated in 1988. He holds a PhD (Doctor of Environmental Earth Sciences) obtained in 1997 at Hokkaido University, Sapporo, Japan and PhD. (land hydrology, water resources and hydrochemistry), obtained in 1998. He was working in Institute of Geography RAS; Institute of Low Temperature Sciences, Sapporo, and National Research Institute for Earth Science and Disaster Prevention, Shinjo, Japan; Graduate School and the Cooperative Institute for Research in Environmental Sciences / National Snow and Ice Data Center and World Data Center for Glaciology, University of Colorado at Boulder, U.S.A.; Swiss Federal Institute for Forest, Snow, and Landscape Research / Swiss Federal Institute for Snow and Avalanche Research, Davos, Switzerland. Recently he is Senior Research Scientist at the MSU Faculty of Geography. His research interest includes all possible aspects of snow and snow cover research. List of publications is available at: http://istina.imec.msu.ru/accounts/profile/ sokratov/. 


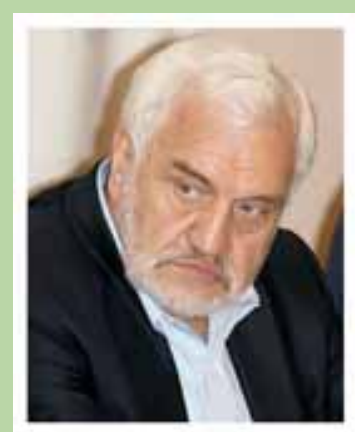

Klaus Peter Koltermann studied Oceanography, Meteorology and Geophysics at Hamburg University, graduating in 1968 (Diploma) with a thesis modelling seiches in the Baltic/North Sea Seas. He worked at the then DeutschesHydrographischesInstitut DHI, Hamburg, on currents, hydrography of shelf seas, large-scale ocean circulation with contributing to or leading extensive cruises in the North Sea, North Atlantic,Arctic and Antarctic Oceans. In 1988 he obtained a degree of Dr rernat from Hamburg University with a thesis on the deep circulation of the Greenland Sea. He gave lectures at Hamburg University (Polar Oceanography, the Equation of State of Seawater). From 1987 to 1991 he was Director of the WOCE International Project Office at the IOS, Wormley, UK. Returning to the renamed DHI, now BSH, in 1991 he was engaged in research focused on the ocean's role in the climate system, estimating the transports of heat and freshwater in the North Atlantic and providing consistent oceanographic data sets. After the Indian Ocean tsunami in 2004 he led the Tsunami Group of the Intergovernmental Oceanographic Commission, UNESCO, in Paris from 2006-2010 to establish tsunami early warning systems in all oceans. Since December 2010 he is the Leading Scientist of the Natural Risk Assessment Laboratory at the Faculty of Geography, Moscow State University, established under the Russian Mega-grant programme.

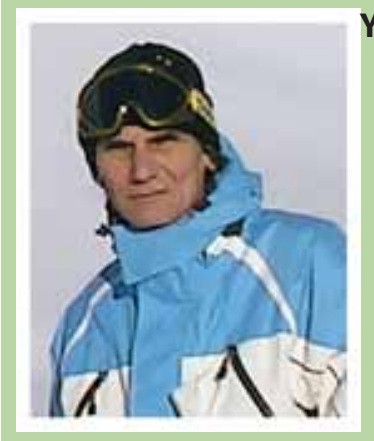

Yury G. Seliverstov graduated from Moscow State University (Faculty of Geography) in 1985. Since 1989 he is research scientist at the Laboratory of Snow Avalanches and Debris Flows, Faculty of Geography, MSU. The fields of his scientific activity include geography of avalanches, risk analysis, GIS approach. The geography of his field investigations covers practically all regions of Russia. He published more than 60 scientific publications, main of them are: Snow avalanches: danger and risk at the territory of Russia (2009); Snow avalanches at the plain (2008); Macrocirculation conditions of mass snow avalanches formation (2009).

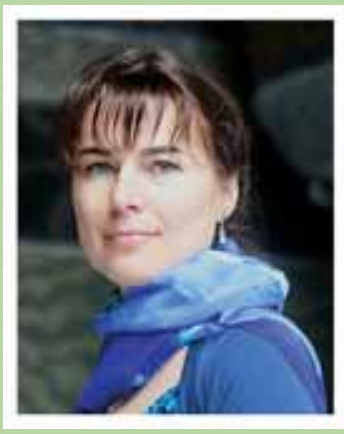

Marina A. Vikulina studied geomorphology at the Faculty of Geography, Lomonosov Moscow State University and graduated with Master degree in 2000. Since January 2001 she is working at the Khibiny educational and scientific base, MSU Faculty of Geography, recently as the scientific researcher. She obtained PhD. degree in 2010. Her research focuses on snow avalanches, GIS technologies and the concept of risk. Main publications: Assessment of snow avalanche hazard: methods and results (2010); Assessment of snow avalanche activity, hazard and risk (with Khibiny Mountains as an example) (2009); The modeling of unstable conditions of snow on a slope with the use of GIS technologies (2007, co-author Chernous, P. A.). 